\title{
REVIEW
}

\section{ASSESSING NURSE PROFESSIONALISM: A LITERATURE REVIEW OF INSTRUMENTS AND THEIR MEASUREMENT PROPERTIES}

\author{
Katarína Žiaková $(D)$ Dominika Kalánková ${ }^{(D)}$, Martina Tomagová $(i)$ \\ Department of Nursing, Jessenius Faculty of Medicine in Martin, Comenius University in Bratislava, Martin, Slovakia
}

Received December 16, 2020; Accepted May 6, 2021. Copyright: This is an open access article under the CC BY-NC-ND license.

\begin{abstract}
Aim: To provide an overview of instruments measuring nurse professionalism, and to analyze and critically evaluate the psychometric properties of these instruments. Design: A narrative literature review. Methods: A search was made for studies focusing on instruments measuring nurse professionalism using relevant terms. The literature search was conducted between September and December 2020 in two scientific databases: Scopus, and ProQuest. A total of eleven studies featuring instruments to measure nurse professionalism were included in the analysis. A content analysis approach was adopted. Results: We identified eleven self-report instruments measuring nurse professionalism, seven of which were designed to measure nurse professionalism in general, and four which measured more specific concepts, such as nursing values or nurse-nurse collaboration. The instruments demonstrated acceptable psychometric properties. Conclusion: There is a lack of research focusing on nurse professionalism in a European context, and in Slovakia in particular. With increasing demands on nursing care, it is necessary to examine this phenomenon within nursing practice. We, therefore, recommend that research be conducted using instruments to measure nurse professionalism in Europe and in Slovakia.
\end{abstract}

Keywords: instrument, nursing, nurses, professionalism, psychometric properties.

\section{Introduction}

Nowadays, internationally, focus is placed on the provision of quality nursing care, patient safety, patient outcomes, teamwork, job satisfaction, and satisfaction with the work environment. Likewise, cost-effective and safe care, together with competent and high-quality service providers, are necessary throughout healthcare systems all over the world. Experienced and highly professional nurses are required to satisfy these demands and needs (De Braganca \& Nirmala, 2017). Nurses have a responsibility to regularly attain and actuate nursing competencies (Ghadirian et al., 2014), and to demonstrate their professionalism in clinical practice to positively impact patient satisfaction and patient outcomes (Fukada, 2018). Nurses must take responsibility for their actions, understand and manage floating work conditions and situations, and keep abreast of the increasing demands and changes in the provision of nursing care (Skela-Savič et al., 2017).

The term "professionalism" has been discussed for decades in international scientific literature; however,

Corresponding author: Dominika Kalánková, Department of Nursing, Jessenius Faculty of Medicine in Martin, Comenius University in Bratislava, Malá Hora 5, Martin, Slovakia; email: kalankoval@uniba.sk many researchers agree that the phenomenon has not yet been sufficiently investigated (Johnson, 2015). Generally, professionalism involves the representation of attitudes relating to identification with and commitment to a particular profession. A professional is developed through a process of socialization, beginning with formal education to acquire initial knowledge and skills (Ghadirian et al., 2014; Johnson, 2015). Professionalism is a term that refers to the behavior of individual professionals, demonstrated through interactions with patients or clients. The phenomenon might be defined as the degree of personal commitment to the values and characteristics of behavior which relate to a specific career identity (Miller et al., 1993). Professionalism is a multidimensional construct including intrapersonal, interpersonal, and public aspects. It represents the set of attitudes and behaviors that are considered adequate for a particular profession (De Braganca \& Nirmala, 2017; Schmidt \& McArthur, 2018), and is manifested in a conceptualization of attributes, interactions, responsibilities, attitudes, and behaviors required of professionals in interactions with clients and society as a whole, and relates to behavior, goals and characteristics that define professionals or their professions (Fitzgerald, 2020).

The American researcher, Richard H. Hall, developed one of the first frameworks for the interpretation and 
evaluation of professionalism. This framework is widely applicable in different professional fields (Hampton \& Hampton, 2000; Kim-Godwin et al., 2010; Wynd, 2003). Hall's work suggested that individuals' degree of professionalism might be assessed through their attitudes, and that these attitudes correspond highly with their behaviors (Miller et al., 1993). Hall identified five attitudinal attributes of individuals that are involved in professionalism: belief in public service, use of a professional organization as a major referent, belief in autonomy, sense of calling to the field, and belief in self-regulation (Hall, 1968). However, due to the specific nature of nursing, standard indexes of professionalism were found to be inadequate for the evaluation of professionalism in nursing. Miller (1988) published the most well-known template for nurse professionalism - the Wheel of Professionalism in Nursing, representing a model of professional behaviors. The model includes nine categories relating to professionalism in nursing: educational background; adherence to the code of ethics; participation in a professional organization; continuing education and competency; communication and publication; autonomy and selfregulation; community service; theory use, development, and evaluation; and involvement in research. Based on the above model, a self-report instrument: the Behavioral Inventory Form for Professionalism in Nursing, was developed (Miller et al., 1993). Several other instruments have since been developed and published in nursing journals, and adapted for use in different countries (e.g. Gunduzoglu et al., 2017; Jahromi et al., 2018; Tanaka et al., 2016). These measuring tools mainly aim to identify degree of professionalism, or focus on more specific concepts, such as nursing values or collaboration. Use of these instruments to assess and evaluate nurse professionalism may result in further research and extension of knowledge in the nursing profession. If nurses have the opportunity to develop their knowledge and skills, they might experience advanced feelings of professional autonomy and thereby improve their professional values and increase their job satisfaction (De Braganca \& Nirmala, 2017). With regard to nursing education, key aspects of professionalism should be integrated from the beginning of nursing courses and reinforced continuously throughout study. Thus, evaluation of professionalism should start at schools of nursing, and lecturers should use every opportunity to demonstrate model behaviors and include the primary key terms related to professionalism throughout the entire curriculum (Shepard, 2014). Finally, nurse managers may benefit from using specific instruments to reveal factors that influence nurse professionalism, such as workload or poor working conditions, and to encourage nurses to enhance their professionalism (Miller et al., 1993). However, to the authors' knowledge, no overview of instruments measuring professionalism has been published in the literature. Hence, our literature review aimed to provide an overview of such instruments, and to evaluate their psychometric properties in order to identify valid and reliable instruments that could be used to measure nurse professionalism.

\section{Aim}

The literature review aimed to provide an overview of instruments measuring nurse professionalism, and to analyze and critically evaluate their psychometric properties.

The specific research questions were:

1) What instruments measuring nurse professionalism are available in the literature, and what are their basic characteristics?

2) What are the psychometric properties of the instruments that measure nurse professionalism?

\section{Methods}

\section{Design}

A narrative literature review. The review was conducted according to the PRISMA checklist (Preferred Reporting Items for Systematic Reviews and Meta-Analyses).

\section{Eligibility criteria}

The search included all studies published up to September 2020 meeting predefined criteria: 1) empirical articles; 2) quantitative research methods; 3) published in peer-reviewed journals; 4) written in English; 5) with a focus on the topic of interest (instruments measuring nurse professionalism); and 6) involving nurses (e.g. nurse managers, nurse educators, nurse practitioners, registered nurses). Exclusion criteria were: 1) editorials, reviews, protocols, case studies; 2) studies using mixed-method or qualitative research methods.

\section{Search Strategy}

A systematic literature search was conducted in two scientific databases, ProQuest (studies published up to September 2020) and Scopus (studies published up to September 2020) on 23 September 2020. The databases were selected based on their institutional availability. In both databases, the same key terms were used in search queries: "professionalism" AND "nursing" AND "instrument". The literature search was limited 
to peer-reviewed articles and scholarly journals at title / abstract level, written in English. A total of 1,384 papers were found which matched the stated criteria (588 from ProQuest, and 796 from Scopus). A subsequent manual search of reference lists from the included studies produced nine additional papers relating to the topic of interest, increasing the total to 1,393 .

\section{Study Selection inc. PRISMA flow diagram}

The data were systematically retrieved in two phases by two independent researchers (MT, DK), following the PRISMA flow diagram (Figure 1). The program Rayyan QCRI ${ }^{\circledR}$ was used in both retrieval phases (Ouzzani et al., 2016). After removal of duplicates $(n=379)$, a total of 1,014 studies were analyzed using titles, abstracts, and inclusion criteria in the first phase. In the second phase, a total of 21 studies were examined further by reading full-texts until agreement between two independent researchers was achieved. In this phase, the evaluation of particular aspects of instruments' measurement properties was performed according to the COSMIN checklist (COnsensus-based Standards for the selection of health status Measurement Instruments). The COSMIN checklist consists of nine boxes (internal consistency, reliability, structural validity, content validity, cross-cultural validity, criterion validity, responsiveness, measurement error, and hypothesis testing) to rate different aspects of the design, methods, and reporting quality of studies based on instruments' measurement properties (Mokkink et al., 2010). Ten articles which did not contain information about psychometric properties were thereby excluded. Overall, eleven studies were included in the final analysis.

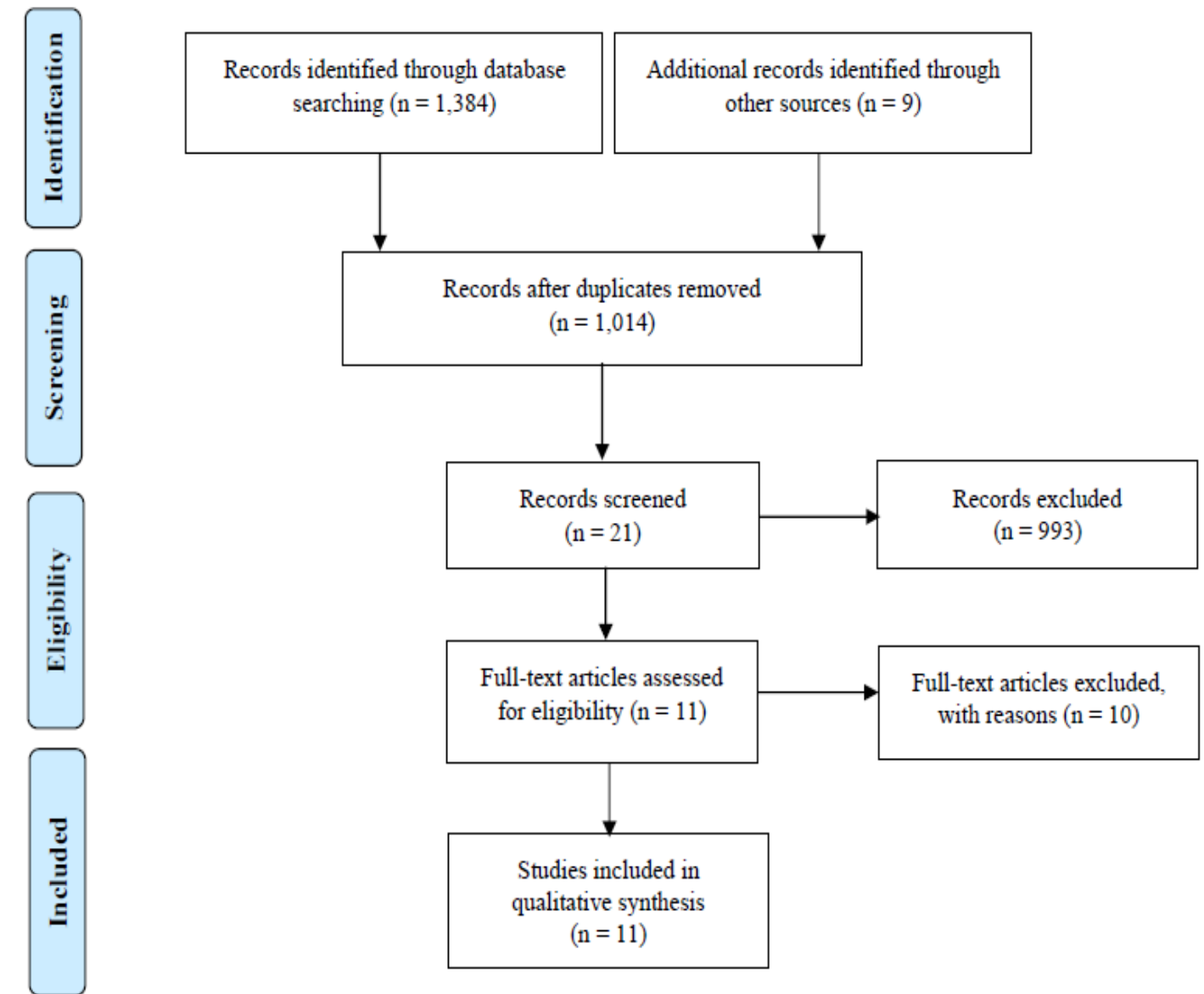

Figure 1 Flow diagram - recommendation PRISMA 


\section{Evaluation of quality of articles}

The quality of included studies was carried out by two independent researchers (MT, DK), using the spreadsheet of the own design (see data extraction). Two independent researchers achieved the agreement during the quality evaluation.

\section{Data extraction}

The researchers extracted the following information from the 11 studies: author, year, country, aim, sampling method, sample size, informants, instrument, area of assessment, evaluation description, and psychometric properties. The synthesis of the data was narrative and tabular. The data were analyzed using the summative content analysis approach, to explore the stated research questions (Hsieh \& Shannon, 2005).

\section{Results}

Research question 1: What instruments measuring nurse professionalism are available in the literature, and what are their basic characteristics?

Eleven scales were included in the literature review (Table 1): seven original instruments (Baumann
\& Kolotylo, 2009; Dougherty \& Larson, 2010; Hall, 1968; Ichikawa et al., 2020; Lin et al., 2016; Miller et al., 1993; Pareek et al., 2016), and four adapted or revised instruments (Adams \& Miller, 2001; Snizek, 1972; Weis \& Schank, 2009, 2017).

Most of the studies included in the review were conducted in the USA $(n=7)$. Additional studies were conducted in Canada, Japan, Taiwan, and India (one in each). Development of items in instruments was based on a literature review $(n=3)$, a combination of literature review and qualitative approach $(\mathrm{n}=3)$, the work of Hall, Wilensky, and Miller $(n=4)$, and for one instrument, the basis was not reported. The number of items in instruments ranged from 25 to 82. Five instruments were divided into five domains, two instruments had nine subscales, and the others had between three and eight domains. With regard to evaluation description, six instruments used a fivepoint Likert scale, and one instrument a four-point Likert scale. Two instruments had dichotomous response options, and one instrument used a continuum of positive and negative responses. Only one tool was reported as using a Likert scale without specifications.

Table 1 Overview of instruments measuring nurse professionalism (Part 1)

\begin{tabular}{|c|c|c|c|c|c|c|}
\hline $\begin{array}{l}\text { Author } \\
\text { (year), } \\
\text { country }\end{array}$ & Aim & $\begin{array}{l}\text { Sampling } \\
\text { method }\end{array}$ & $\begin{array}{l}\text { Sample } \\
\text { size, } \\
\text { informants }\end{array}$ & Instrument & $\begin{array}{l}\text { Areas of the } \\
\text { assessment }\end{array}$ & $\begin{array}{l}\text { Evaluation } \\
\text { description }\end{array}$ \\
\hline $\begin{array}{l}\text { Adams } \\
\& \text { Miller } \\
(2001) \\
\text { USA }\end{array}$ & $\begin{array}{l}\text { to explore the } \\
\text { level of } \\
\text { professionalism } \\
\text { in nurse } \\
\text { practitioners }\end{array}$ & convenience & $\begin{array}{l}\mathrm{n}=502 \\
\text { nurse } \\
\text { practitioners }\end{array}$ & $\begin{array}{l}\text { Professionalism } \\
\text { in Nursing } \\
\text { Behaviors' } \\
\text { Inventory }\end{array}$ & $\begin{array}{l}\text { the overall number of } \\
\text { items = 48; } \\
\text { ten items represent } \\
\text { demographic data and } \\
\text { opinions of } \\
\text { professionalism in } \\
\text { nursing questionnaires; } \\
38 \text { items are grouped } \\
\text { into nine categories: } \\
\text { Educational } \\
\text { preparation; Autonomy; } \\
\text { Theory; Adherence to } \\
\text { the ANA Code of } \\
\text { Ethics; } \\
\text { Participation in } \\
\text { publication; } \\
\text { Participation in } \\
\text { research; Participation } \\
\text { in professional } \\
\text { organizations; } \\
\text { Participation in } \\
\text { community service; } \\
\text { Maintaining } \\
\text { competency }\end{array}$ & $\begin{array}{l}\text { items were } \\
\text { dichotomous and } \\
\text { asked about } \\
\text { behaviors of the } \\
\text { nurse in the past } \\
\text { two years; } \\
\text { behaviors are } \\
\text { weighted to } \\
\text { equal } 3 \text { (within } \\
\text { each category); } \\
\text { a total composite } \\
\text { score of } 27 \text { can } \\
\text { be achieved }\end{array}$ \\
\hline
\end{tabular}


Table 1 Overview of instruments measuring nurse professionalism (Part 2)

\begin{tabular}{|c|c|c|c|c|c|c|}
\hline $\begin{array}{l}\text { Author } \\
\text { (year), } \\
\text { country }\end{array}$ & Aim & $\begin{array}{l}\text { Sampling } \\
\text { method }\end{array}$ & $\begin{array}{l}\text { Sample size, } \\
\text { informants }\end{array}$ & Instrument & $\begin{array}{l}\text { Areas of the } \\
\text { assessment }\end{array}$ & $\begin{array}{l}\text { Evaluation } \\
\text { description }\end{array}$ \\
\hline $\begin{array}{l}\text { Baumann } \\
\text { \& Kolotylo } \\
(2009), \\
\text { Canada }\end{array}$ & $\begin{array}{l}\text { to develop and } \\
\text { test the } \\
\text { psychometric } \\
\text { properties of } \\
\text { questionnaires } \\
\text { intended to } \\
\text { measure key } \\
\text { professionalism } \\
\text { and } \\
\text { environmental } \\
\text { attributes }\end{array}$ & convenience & $\begin{array}{l}\mathrm{n}=848 \\
\text { nurses } \\
\text { (registered } \\
\text { nurses, } \\
\text { licensed } \\
\text { practical } \\
\text { nurses, } \\
\text { registered } \\
\text { practical } \\
\text { nurses) }\end{array}$ & $\begin{array}{l}\text { The } \\
\text { Professionalism } \\
\text { and } \\
\text { Environmental } \\
\text { Factors in the } \\
\text { Workplace } \\
\text { Questionnaire® } \\
\text { (PEFWQ) }\end{array}$ & $\begin{array}{l}\text { the overall number } \\
\text { of items = } 82 \\
\text { (divided into three } \\
\text { sections); } \\
\text { demographic data; } \\
\text { environmental } \\
\text { attributes (Control } \\
\text { of nursing practice; } \\
\text { Quality of nursing } \\
\text { work life; } \\
\text { Professional support; } \\
\text { Shared governance; } \\
\text { Environment culture } \\
\text { and climate); } \\
\text { professionalism } \\
\text { attributes (Autonomy; } \\
\text { Knowledge; } \\
\text { Competence; } \\
\text { Professionhood; } \\
\text { Accountability; } \\
\text { Advocacy; } \\
\text { Collaborative } \\
\text { practice; } \\
\text { Commitment) }\end{array}$ & $\begin{array}{l}\text { five-point } \\
\text { Likert Scale } \\
\text { (from } \\
1=\text { strongly } \\
\text { agree to } \\
5=\text { strongly } \\
\text { disagree) }\end{array}$ \\
\hline $\begin{array}{l}\text { Dougherty } \\
\text { \& Larson } \\
\text { (2010), } \\
\text { USA }\end{array}$ & $\begin{array}{l}\text { to develop a } \\
\text { new instrument } \\
\text { for measuring } \\
\text { nurse-nurse } \\
\text { collaboration, } \\
\text { and to examine } \\
\text { its validity and } \\
\text { reliability }\end{array}$ & not reported & $\begin{array}{l}\mathrm{n}=76 \\
\text { nurses }\end{array}$ & $\begin{array}{l}\text { Nurse-Nurse } \\
\text { Collaboration } \\
\text { Scale }\end{array}$ & $\begin{array}{l}\text { the overall number of } \\
\text { items = } 35 \text { (divided } \\
\text { into five domains); } \\
\text { Problem solving = } 7 \\
\text { items; } \\
\text { Communication = } 8 \\
\text { items; } \\
\text { Coordination = 5 } \\
\text { items; } \\
\text { Shared process = } 8 \\
\text { items; } \\
\text { Professionalism = } 7 \\
\text { items; }\end{array}$ & $\begin{array}{l}\text { four-point } \\
\text { Likert Scale } \\
\text { (from } \\
4=\text { strongly } \\
\text { disagree to } \\
1=\text { strongly } \\
\text { agree) }\end{array}$ \\
\hline $\begin{array}{l}\text { Hall } \\
\text { (1968), } \\
\text { USA }\end{array}$ & $\begin{array}{l}\text { to develop } \\
\text { a tool for } \\
\text { measuring } \\
\text { degree of } \\
\text { professionalism }\end{array}$ & $\begin{array}{l}\text { represent- } \\
\text { ative }\end{array}$ & $\begin{array}{l}\mathrm{n}=328 \\
\text { physicians, } \\
\text { nurses, } \\
\text { accountants, } \\
\text { teachers, } \\
\text { lawyers, } \\
\text { social } \\
\text { workers, } \\
\text { stockbrokers, } \\
\text { librarians, } \\
\text { engineers, } \\
\text { personnel } \\
\text { managers, } \\
\text { and } \\
\text { advertising } \\
\text { executives }\end{array}$ & $\begin{array}{l}\text { Hall's } \\
\text { Professional } \\
\text { Scale }\end{array}$ & $\begin{array}{l}\text { the overall number } \\
\text { of items = 50 } \\
\text { (divided into five } \\
\text { components); } \\
\text { use of a professional } \\
\text { organization; belief } \\
\text { in public service; } \\
\text { autonomy; belief } \\
\text { in self-regulation; } \\
\text { sense of calling }\end{array}$ & $\begin{array}{l}\text { five-point } \\
\text { Likert scale } \\
\text { (from } \\
5=\text { strongly } \\
\text { agree to } \\
1=\text { strongly } \\
\text { disagree) }\end{array}$ \\
\hline
\end{tabular}


Table 1 Overview of instruments measuring nurse professionalism (Part 3)

\begin{tabular}{|c|c|c|c|c|c|c|}
\hline $\begin{array}{l}\text { Author, } \\
\text { (year), } \\
\text { country }\end{array}$ & Aim & $\begin{array}{l}\text { Sampling } \\
\text { method }\end{array}$ & $\begin{array}{l}\text { Sample } \\
\text { size, } \\
\text { informants }\end{array}$ & Instrument & Areas of the assessment & $\begin{array}{l}\text { Evaluation } \\
\text { description }\end{array}$ \\
\hline $\begin{array}{l}\text { Ichikawa } \\
\text { et al. } \\
(2020) \text {, } \\
\text { Japan }\end{array}$ & $\begin{array}{l}\text { to develop } \\
\text { a self-report } \\
\text { assessment } \\
\text { inventory } \\
\text { to evaluate } \\
\text { nurses' } \\
\text { professionalism, } \\
\text { and provide its } \\
\text { psychometric } \\
\text { properties }\end{array}$ & stratified & $\begin{array}{l}\mathrm{n}=5,039 \\
\text { nurses }\end{array}$ & $\begin{array}{l}\text { The Nurses' } \\
\text { Professionalism } \\
\text { Inventory } \\
\text { (NPI) }\end{array}$ & $\begin{array}{l}\text { the overall number } \\
\text { of items = } 28 \text { (divided } \\
\text { into five subscales); } \\
\text { Accountability; Self- } \\
\text { improvement; } \\
\text { Professional attitude; } \\
\text { Advancement of the } \\
\text { nursing profession; } \\
\text { Professional } \\
\text { membership }\end{array}$ & $\begin{array}{l}\text { ten-point Likert } \\
\text { scale (from } \\
1=\text { strongly } \\
\text { disagree to } \\
10=\text { strongly } \\
\text { agree) }\end{array}$ \\
\hline $\begin{array}{l}\text { Lin et al. } \\
(2016), \\
\text { Taiwan }\end{array}$ & $\begin{array}{l}\text { to examine } \\
\text { psychometric } \\
\text { properties of the } \\
\text { Nurse } \\
\text { Practitioners' } \\
\text { Roles and } \\
\text { Competencies } \\
\text { Scale }\end{array}$ & $\begin{array}{l}\text { not } \\
\text { reported }\end{array}$ & $\begin{array}{l}\mathrm{n}=563 \\
\text { nurse } \\
\text { practitioners }\end{array}$ & $\begin{array}{l}\text { The Nurse } \\
\text { Practitioners' } \\
\text { Roles and } \\
\text { Competencies } \\
\text { Scale }\end{array}$ & $\begin{array}{l}\text { the overall number } \\
\text { of items = } 51 \text { (divided } \\
\text { into six domains); } \\
\text { Professionalism = } 20 \\
\text { items; } \\
\text { Direct care = } 12 \text { items; } \\
\text { Clinical research = 5 } \\
\text { items; } \\
\text { Practical guidance = } 4 \\
\text { items; } \\
\text { Medical assistance = } 7 \\
\text { items; } \\
\text { Leadership and reform = } \\
3 \text { items }\end{array}$ & $\begin{array}{l}\text { 5-point Likert } \\
\text { Scale (from } \\
1 \text { = completely } \\
\text { disagree to } \\
5 \text { = completely } \\
\text { agree); } \\
\text { higher scores } \\
\text { indicate more } \\
\text { significant } \\
\text { agreement with } \\
\text { the required } \\
\text { nurse } \\
\text { practitioners' } \\
\text { roles and } \\
\text { competencies }\end{array}$ \\
\hline $\begin{array}{l}\text { Miller et } \\
\text { al. } \\
\text { (1993), } \\
\text { USA }\end{array}$ & $\begin{array}{l}\text { to develop } \\
\text { a Behavioral } \\
\text { evaluative } \\
\text { instrument for } \\
\text { Professionalism } \\
\text { in Nursing }\end{array}$ & random & $\begin{array}{l}\mathrm{n}=515 \\
\text { registered } \\
\text { nurses }\end{array}$ & $\begin{array}{l}\text { A Behavioral } \\
\text { Inventory Form } \\
\text { for } \\
\text { Professionalism } \\
\text { in Nursing } \\
(\mathrm{BIPN})^{*}\end{array}$ & $\begin{array}{l}\text { the overall number } \\
\text { of items = } 38 \text { (divided } \\
\text { into nine categories); } \\
\text { ducational background; } \\
\text { adherence to the code } \\
\text { of ethics; } \\
\text { participation in } \\
\text { a professional } \\
\text { organization; continuing } \\
\text { education and } \\
\text { competency; } \\
\text { communication and } \\
\text { publication; autonomy } \\
\text { and self-regulation; } \\
\text { community service; } \\
\text { theory use, development } \\
\text { and evaluation; } \\
\text { research involvement }\end{array}$ & $\begin{array}{l}\text { items were } \\
\text { dichotomous and } \\
\text { asked for } \\
\text { behaviors of the } \\
\text { nurse in the past } \\
\text { two years; } \\
\text { behaviors are } \\
\text { weighted to } \\
\text { equal } 3 \text { (within } \\
\text { each category); } \\
\text { a total composite } \\
\text { score of } 27 \text { can } \\
\text { be achieved }\end{array}$ \\
\hline $\begin{array}{l}\text { Pareek } \\
\text { et al. } \\
\text { (2016), } \\
\text { India }\end{array}$ & $\begin{array}{l}\text { to develop a } \\
\text { scale measuring } \\
\text { professionalism } \\
\text { in nurse } \\
\text { educators }\end{array}$ & judgmental & $\begin{array}{l}\mathrm{n}=30 \\
\text { nurse } \\
\text { educators }\end{array}$ & $\begin{array}{l}\text { The } \\
\text { Professionalism } \\
\text { Assessment } \\
\text { Scale for Nurse } \\
\text { Educator }\end{array}$ & $\begin{array}{l}\text { the overall number of } \\
\text { items = } 34 \text { (divided into } \\
\text { eight domains); } \\
\text { knowledge; spirit } \\
\text { of inquiry; } \\
\text { accountability; } \\
\text { advocacy; innovation; } \\
\text { collegiality and } \\
\text { collaboration; ethics and } \\
\text { values; citizenship and } \\
\text { professional engagement }\end{array}$ & $\begin{array}{l}\text { a continuum } \\
\text { of positive and } \\
\text { negative } \\
\text { response } \\
\text { (positive } \\
\text { response: always } \\
+3 \text {; usually }+2 \text {; } \\
\text { sometimes }+1 ; \\
\text { negative } \\
\text { response: once } \\
\text { in a great while - } \\
1 \text {; rarely }-2 ; \\
\text { never }-3 \text { ) }\end{array}$ \\
\hline
\end{tabular}


Table 1 Overview of instruments measuring nurse professionalism (Part 4)

\begin{tabular}{|c|c|c|c|c|c|c|}
\hline $\begin{array}{l}\text { Author, } \\
\text { (year), } \\
\text { country }\end{array}$ & Aim & $\begin{array}{l}\text { Sampling } \\
\text { method }\end{array}$ & $\begin{array}{l}\text { Sample size, } \\
\text { informants }\end{array}$ & Instrument & $\begin{array}{l}\text { Areas of the } \\
\text { assessment }\end{array}$ & $\begin{array}{l}\text { Evaluation } \\
\text { description }\end{array}$ \\
\hline $\begin{array}{l}\text { Snizek } \\
(1972), \\
\text { USA }\end{array}$ & $\begin{array}{l}\text { to provide } \\
\text { a shorter } \\
\text { reliable } \\
\text { version of } \\
\text { Hall's original } \\
\text { scale }\end{array}$ & $\begin{array}{l}\text { not } \\
\text { reported }\end{array}$ & $\begin{array}{l}\mathrm{n}=566 \\
\text { aeronautical, } \\
\text { nuclear and } \\
\text { chemical } \\
\text { engineers, } \\
\text { physicists } \\
\text { and chemists }\end{array}$ & $\begin{array}{l}\text { Snizek-revised } \\
\text { Hall's } \\
\text { Professionalism } \\
\text { Inventory } \\
\text { Scale*** }\end{array}$ & $\begin{array}{l}\text { the overall number } \\
\text { of items = } 25 \text { (divided } \\
\text { into five components); } \\
\text { use of a professional } \\
\text { organization; belief } \\
\text { in public service; } \\
\text { autonomy; belief in self- } \\
\text { regulation; } \\
\text { sense of calling }\end{array}$ & $\begin{array}{l}\text { five-point Likert } \\
\text { scale (from } \\
5=\text { strongly } \\
\text { agree to } \\
1=\text { strongly } \\
\text { disagree) }\end{array}$ \\
\hline $\begin{array}{l}\text { Weis \& } \\
\text { Schank } \\
(2009), \\
\text { USA }\end{array}$ & $\begin{array}{l}\text { to investigate } \\
\text { the } \\
\text { psychometric } \\
\text { properties } \\
\text { of the revised } \\
\text { Nurse } \\
\text { Professional } \\
\text { Values Scale }\end{array}$ & random & $\begin{array}{l}\mathrm{n}=782 \\
\text { baccalaureate } \\
\text { nursing } \\
\text { students, } \\
\text { graduate } \\
\text { nursing } \\
\text { students, } \\
\text { practising } \\
\text { nurses }\end{array}$ & $\begin{array}{l}\text { Nurse } \\
\text { Professional } \\
\text { Values Scale- } \\
\text { Revised }\end{array}$ & $\begin{array}{l}\text { the overall number } \\
\text { of items = } 26 \text { (divided } \\
\text { into five domains); } \\
\text { Caring = } 9 \text { items; } \\
\text { Activism = } 5 \text { items; } \\
\text { Trust = } 5 \text { items; } \\
\text { Professionalism = } 4 \\
\text { items; } \\
\text { Justice = } 3 \text { items }\end{array}$ & $\begin{array}{l}\text { five-point Likert } \\
\text { Scale (from } \\
1=\text { not important } \\
\text { to } 5=\text { most } \\
\text { important); } \\
\text { range of scores is } \\
26 \text { to } 130 ; \\
\text { the higher the } \\
\text { score, the } \\
\text { stronger nurses' } \\
\text { professional } \\
\text { value orientation }\end{array}$ \\
\hline $\begin{array}{l}\text { Weis } \\
\& \text { Schank } \\
(2017), \\
\text { USA }\end{array}$ & $\begin{array}{l}\text { to examine the } \\
\text { psychometric } \\
\text { properties } \\
\text { of The Nurses } \\
\text { Professional } \\
\text { Values - } 3\end{array}$ & random & $\begin{array}{l}\mathrm{n}=1,139 \\
\text { baccalaureate } \\
\text { nursing } \\
\text { students, } \\
\text { graduate } \\
\text { nursing } \\
\text { students, } \\
\text { practising } \\
\text { nurses }\end{array}$ & $\begin{array}{l}\text { Nurse } \\
\text { Professional } \\
\text { Values Scale - } \\
3\end{array}$ & $\begin{array}{l}\text { the overall number } \\
\text { of items = } 28 \text { (divided } \\
\text { into three domains); } \\
\text { Caring = } 10 \text { items; } \\
\text { Activism = } 10 \text { items; } \\
\text { Professionalism = } 8 \\
\text { items }\end{array}$ & $\begin{array}{l}\text { five-point Likert } \\
\text { Scale (from } \\
1=\text { not important } \\
\text { to } 5=\text { most } \\
\text { important); } \\
\text { range of scores is } \\
28 \text { to } 140 ; \\
\text { the higher } \\
\text { the score, } \\
\text { the stronger } \\
\text { nurses' } \\
\text { professional } \\
\text { value orientation }\end{array}$ \\
\hline
\end{tabular}

*The most frequently used instrument for measuring nurse professionalism.

**The second most frequently used instrument for measuring nurse professionalism; however, not validated on the sample of nurses.

Theoretical frameworks for instruments differed across studies. Two of the most common theoretical frameworks, well established in sociology, were those of Hall (Hall, 1968; Snizek, 1972) and Miller (Adams \& Miller, 2001; Miller et al., 1993). However, most of the instruments were developed according to comprehensive or critical literature reviews (Dougherty \& Larson, 2010; Pareek et al., 2016); for example, a critical review of the literature on the code of ethics, values, and professional values development was the basis for the Nurse Professional Values scale (Weis \& Schank, 2009, 2017). Likewise, a review of self-improvement, the advancement of the nursing profession, professional attitudes, accountability, and professional membership was the fundamental basis for another scale measuring professionalism (Ichikawa et al., 2020). A review of the literature on professionalism and practice environment was the basis for the PEFWQ ${ }^{\circledR}$ (Baumann \& Kolotylo, 2009). An instrument measuring nurse practitioners' roles and competencies was based on a review of studies conducted in Taiwan, and relevant nurse practitioners' competencies (Lin et al., 2016).

Most instruments included in the review focused on investigating professional behavior as a particular aspect of professionalism (Adams \& Miller, 2001; Baumann \& Kolotylo, 2009; Hall, 1968; Miller et al., 1993; Pareek et al., 2016; Snizek, 1972). Some scales focused on more specific concepts, such as collaboration between nurses (Dougherty \& Larson, 2010), professional values (Weis \& Schank, 2009; 2017), or roles and competencies of nurses (Lin et al., 2016). One recently developed instrument for 
measuring beliefs, attitudes, and behaviors associated with professionalism (Ichikawa et al., 2020) was determined to be the only comprehensive instrument measuring this concept in our study.

Research question 2: What are the psychometric properties of the instruments measuring nurse professionalism?

Instruments included in the review were validated in various settings and on numerous samples of respondents. The most common settings were various wards, including intensive care units, (e.g. Dougherty \& Larson, 2010) in different types of public and private hospitals or medical centres (e.g. Baumann \& Kolotylo, 2009; Ichikawa et al., 2020; Pareek et al., 2016). The predominant group of respondents were nurses, including registered nurses or licenced practical nurses (Baumann \& Kolotylo, 2009; Dougherty \& Larson, 2010; Ichikawa et al., 2020; Miller et al., 1993), nurse educators (Pareek et al., 2016), and nurse practitioners (Adams \& Miller, 2001; Lin et al., 2016). Four instruments were validated on different samples of physicians, nurses, accountants, teachers, lawyers, social workers, stockbrokers, librarians, engineers, personnel managers, and advertising executives (Hall, 1968), baccalaureate nursing students, graduate nursing students, and practising nurses (Weis \& Schank, 2009, 2017), and aeronautical, nuclear, and chemical engineers, physicists, and chemists (Snizek, 1972).

The most frequently reported psychometric properties across the eleven included studies were: internal consistency using the Cronbach alpha coefficient, construct validity, content validity, and reliability testing. Conversely, the least reported psychometric measurements were: hypothesis testing, concurrent validity, and face validity (Table 2).

The Professionalism in Nursing Behaviors' Inventory (Adams \& Miller, 2001) was adapted from the previously published work of Miller et al. (1993). The instrument was adapted for use on nurse practitioners. With regard to psychometric properties, only content validity and internal consistency were reported. Content validity was established by nurses who were employed in different educational and practice areas. The Cronbach alpha coefficient was estimated for the scale $(\alpha=0.74)$.

The Professionalism and Environmental Factors in the Workplace Questionnaire ${ }^{\circledR}$ (Baumann \& Kolotylo, 2009) was based on a literature critique regarding professionalism and environment by content experts from the targeted population and researchers. Content validity was established by content experts and members of the target population. Face validity was assessed by two volunteers from the authors' workplace, who reviewed the instrument for readability, language, title, and instructions. The construct validity was tested by Principal Axis Factoring with Equamax rotation, which resulted in a 15-factor solution (eigenvalues $>1.0$ ) for the instrument, with item factor loadings from 0.32 to 0.82 . Fifteen factors explained $52.27 \%$ of the variance; however, the scree plot suggested a 13 -factor solution. After parallel analysis confirmation, a 13-factor solution for the instrument was adopted. Analysis of the construct validity resulted in an 82item questionnaire. The instrument's reliability was analyzed by test-retest coefficients, which generally indicated scale stability $(r=0.44-0.70 ; p<0.01$, twotailed). Item total correlations were acceptable for the instrument $(\mathrm{r}=0.30-0.60)$ and for the subscales $(r=0.42-0.81)$. Cronbach's alpha coefficient was estimated for the scale $(\alpha=0.96)$ and subscales $(\alpha=0.75-0.92)$.

The Nurse-Nurse Collaboration Scale (Dougherty \& Larson, 2010) was developed from a review of health and social sciences literature. Several items were extracted from existing instruments, such as the ICU MD / RN Questionnaire, Difficulty with the Care of the Terminal Cancer Patient Scale, and the Individual Nurse Questionnaire. Four nursing faculty members assessed the instrument's content for relevance and clarity of items, resulting in $100 \%$ concurrence on a content rating of three or four for all items. Construct validity was tested using the interscale correlations $(\mathrm{r}=0.21-0.61) . \mathrm{R}^{2}$ ranged from 0.04 to 0.21 , indicating that the scale measured individual domains contributing to the concept of collaboration rather than a single, global construct. For internal consistency, Cronbach's alpha coefficient was estimated for the scale $(\alpha=0.89)$ and subscales $(\alpha=0.66-0.91)$.

Hall's Professional Inventory (Hall, 1968) was developed based on the work of Wilensky (1964). Only internal consistency of the instrument was reported for the scale $(\alpha=0.86)$ and for the subscale $(\alpha \geq 0.80)$. Interestingly, the author validated the instrument on a sample of various health professionals, including physicians and nurses.

The Nurses' Professionalism Inventory - NPI (Ichikawa et al., 2020) was the only instrument with almost all psychometric properties reported adequately. The scale was based on an extensive literature review and interviews with seven expert registered nurses, and short interviews with eight external contributors (physicians, journalists, the head of a patient's association) who explained what they expected of nurses who exhibited professionalism. 
Table 2 Psychometric properties of instruments measuring nurse professionalism

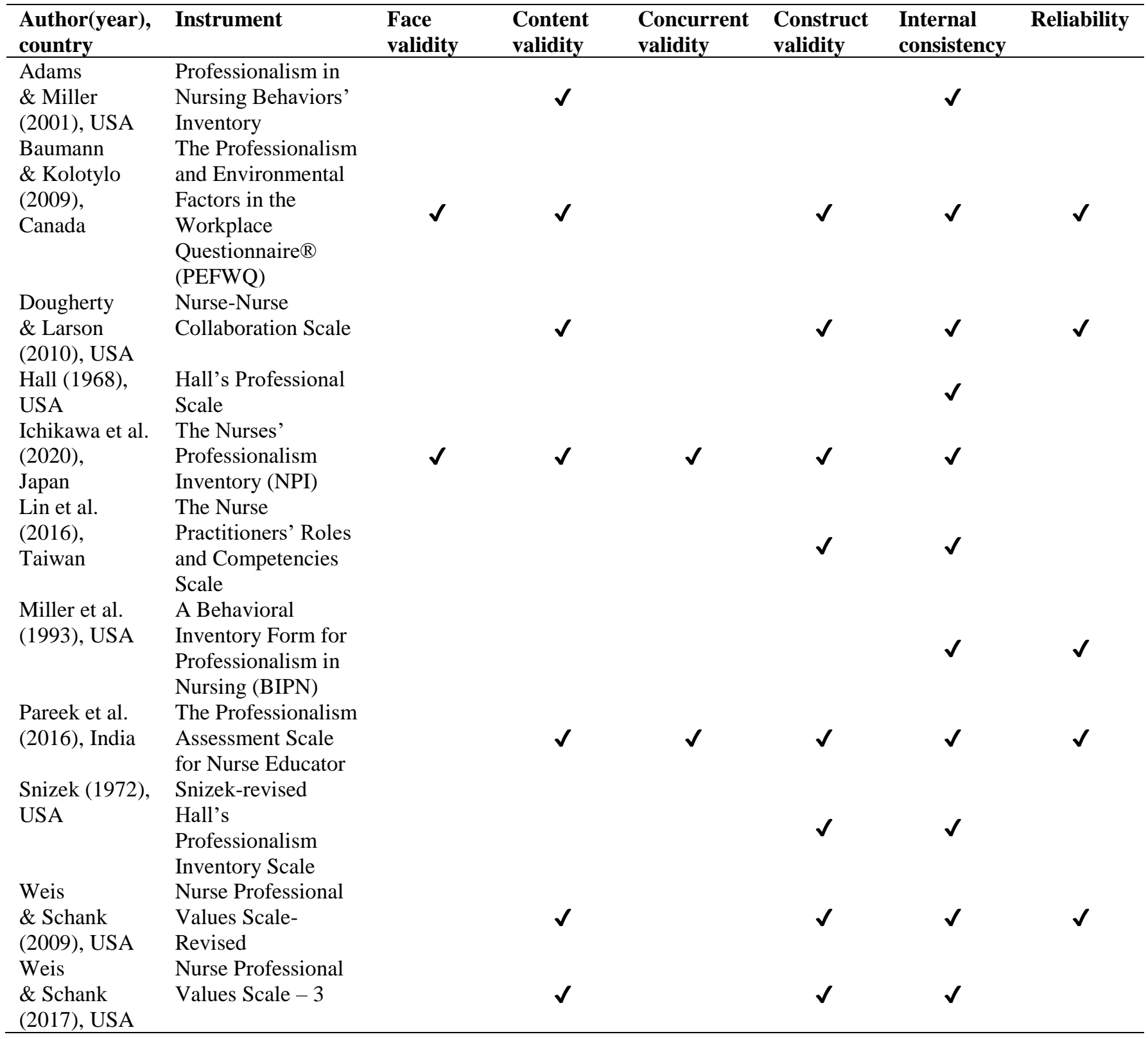

Face validity was established by a pilot survey involving ten nurses. Content validity was established by six researchers, who reviewed the items for clarity and relevance. Construct validity was tested by Exploratory Factor Analysis, which resulted in a fivefactor solution (eigenvalues > 1.0). Five factors explained $62.4 \%$ of the variance. Confirmatory factor analysis confirmed a five-factor solution for the instrument. Concurrent validity was assessed via correlations between NPI subscales and two overall items. Correlations were significant $(\mathrm{p}<0.01)$. Cronbach's alpha coefficient was estimated for the scale $(\alpha=0.95)$ and subscales $(\alpha=0.84-0.90)$

The Nurse Practitioners' Roles and Competencies Scale (Lin et al., 2016) was examined for construct validity and internal consistency. Construct validity was examined by Principal Component Analysis, using the Varimax rotation method, which resulted in a six-factor solution (eigenvalues >1.0), with item factor loadings ranging from 0.41 to 0.86 . Six factors explained $67.5 \%$ of the variance. Cronbach's alpha coefficient was estimated for the scale $(\alpha=0.98)$ and subscales $(\alpha=0.83-0.97)$.

The Behavioral Inventory Form for Professionalism in Nursing (Miller et al., 1993) is the most common instrument for measuring nurse professionalism worldwide. The scale was based on a literature review and the work of Hall (1968). Only reliability and internal consistency were reported in the validation study. The stability of the instrument was confirmed by administering the tool to nurses from different settings and different geographical areas. Cronbach's 
alpha coefficient was estimated for subscales $(\alpha=0.82-0.87)$.

The Professionalism Assessment Scale for Nurse Educator (Pareek et al., 2016) was based on a literature review, existing scales, expert opinions, focus group discussions, and peer discussions. Content validity was assessed via the Content Validity Index (at least $70 \%$ for any given items; the same criterion for the scale). Convergent validity was confirmed by monotrait-monomethod, with similar scales indicating high convergent validity (0.91). Divergent validity was proved using the Occupational Burnout Inventory with negative correlation (-0.48). Construct validity was tested by Principal Component Analysis, using Varimax rotation with Kaiser Normalization, which resulted in a nine-factor solution (eigenvalues $>1.0$ ). Nine factors explained $83.14 \%$ of the variance. Cronbach's alpha coefficient was estimated for the scale $(\alpha=0.92)$. The results of the test-retest $(p=0.89)$ proved the stability of the instrument.

Hall's Professionalism Inventory Scale, revised by Snizek (Snizek, 1972), was an adaptated version of Hall's Professional Scale (Hall, 1968). Construct validity, and internal consistency were analyzed. Construct validity was tested by Principal Component Analysis using Varimax rotation, which resulted in a five-factor solution. The five factors indicated half the number of items included in Hall's original scale. Cronbach's alpha coefficient was estimated for the scale $(\alpha=0.78)$.

The Nurse Professional Values Scale-Revised (Weis \& Schank, 2009) was based on a critical review of the literature on the code of ethics, values, and professional values development in nurses. Content validity was assessed by four experts on the code of ethics for nurses (nurse educators, nurse practitioners) for relevance, readability, meaning, and clarity of items. Construct validity was examined using Principal Component Analysis, which resulted in a five-factor solution (eigenvalues $>1.0$ ), with item factor loadings of more than 0.40. Five factors explained $56.7 \%$ of the variance. Confirmatory factor analysis confirmed the five-factor solution. Cronbach's alpha coefficient was estimated for the scale $(\alpha=0.92)$ and subscales $(\alpha=0.70-0.92)$.

The Nurse Professional Values Scale-3 - NPVS-3 (Weis \& Schank, 2017) is a revised instrument based on a critical review of the literature on the code of ethics, values, and professional values development in nurses. In accordance with the code of ethics framework, changes were made resulting in the development of the NPVS-3. Content validity was assessed by three experts on the code of ethics for nurses (nurse educators, nurse practitioners) for relevance, readability, meaning, and clarity of items. Construct validity was examined using Principal Component Analysis with Varimax rotation and Kaiser Normalization, which resulted in a threefactor solution (eigenvalues > 1.0), with item factor loadings of more than 0.30 . Three factors explained $51.62 \%$ of the variance. Confirmatory factor analysis confirmed the three-factor solution. Cronbach's alpha coefficient was estimated for the scale $(\alpha=0.94)$ and subscales $(\alpha=0.79-0.91)$.

\section{Discussion}

The narrative literature review focused on instruments measuring nurse professionalism, and an evaluation of their psychometric properties. For the first stated research question, we identified eleven instruments. These instruments focus specifically on nurse professionalism (e.g. Adams \& Miller, 2001; Snizek, 1972) or a related concept, such as nursing values or nurse collaboration (e.g. Dougherty \& Larson, 2010; Weis \& Schank, 2009).

The most frequently used instrument for measuring nurse professionalism was the Behavioral Inventory Form for Professionalism in Nursing, based on Miller's Wheel of Professionalism in Nursing (Miller et al., 1993). Most studies were conducted in Asia (e.g. Cerit \& Dinç, 2013; Dikmen et al., 2016; Hisar \& Karadağ, 2010; Konukbay et al., 2014; Tanaka et al., 2016); with no study conducted in a European context. Hall's Professional Inventory Scale, based on Hall's work and revised by Snizek, is a widely-used instrument, especially in American settings (e.g. KimGodwin et al., 2010; Wynd, 2003), although the inventory has also been validated in other countries, such as China (Chen et al., 2019), Korea (Jang et al., 2016; Kim \& Baek, 2007), and Iran (Doost et al., 2016; Shohani \& Zamanzadeh, 2017). Other studies using instruments to measure nurse professionalism were conducted mainly in the USA, China, Korea, and Iran. Generally, there is an absence of literature relating to the investigation of nurse professionalism in a European context. Worldwide, levels of professionalism among nurses were reported as low (Çelik \& Hisar, 2012; Cerit \& Dinç, 2013; Hisar \& Karadağ, 2010; Poorchangizi et al., 2019; SkelaSavič et al., 2017; Tanaka et al., 2014) to average (Castro et al., 2016; Shohani \& Zamanzadeh, 2017). The most highly evaluated domains of professionalism across studies were competence and continuing education (Adams \& Miller, 2001; Dikmen et al., 2016; Konukbay et al., 2014; Miller et al., 1993; Tanaka et al., 2016), and use of theory (Adams et al., 1996; Adams \& Miller, 2001; Cerit \& Dinç, 2013; Miller et al., 1993). Educational preparation and use 
of theory were reported as the most highly evaluated domains among nurses in Poland. In contrast, among nurses in Belarus and Iran, the most highly evaluated subscale of professionalism was professional organizations (Marcinowicz et al., 2020; Shohani \& Zamanzadeh, 2017). The domains of professionalism with lowest assessments were publication (Adams et al., 1996; Adams \& Miller, 2001; Cerit \& Dinç, 2013; Dikmen et al., 2016; Konukbay et al., 2014; Miller et al., 1993; Tanaka et al., 2016), communication (Tanaka et al., 2016), professional organization (Adams et al., 1996; Konukbay et al., 2014), autonomy (Cerit \& Dinç, 2013; Dikmen et al., 2016; Konukbay et al., 2014; Shohani \& Zamanzadeh, 2017), and research (Adams et al., 1996; Adams \& Miller, 2001; Dikmen et al., 2016; Miller et al., 1993).

Nurse professionalism was associated with the educational level of nurses (Dikmen et al., 2016), current position in nursing, current employment status (Kim-Godwin et al., 2010), total years of nursing experience (Doost et al., 2016; Kim-Godwin et al., 2010; Shohani \& Zamanzadeh, 2017; Tanaka et al., 2016), participation in training courses for individual empowerment (Shohani \& Zamanzadeh, 2017), age of nurses (Doost et al., 2016), job satisfaction (Çelik \& Hisar, 2012; Jang et al., 2016), nurses' principled thinking level (Cerit \& Dinç, 2013), and work setting (Baumann et al., 2016; Kim-Godwin et al., 2010).

In response to the second research question, we found that measurement properties of instruments included in the review were quite poorly reported across studies. The most frequently reported measurement properties were those relating to internal consistency and construct validity, followed by content validity and reliability. Besides the validation studies included in our review, few research studies have explored specific instruments' psychometric properties (e.g. Jahromi et al., 2018; Marcinowicz et al., 2020). In our review, psychometric properties were demonstrated to be acceptable; however, there is a gap in the literature in terms of more in-depth and systematic exploration, and testing in various settings and socio-cultural contexts.

\section{Limitation of study}

The review is limited in that it included only studies published in English in databases available at the institution where the study was conducted. Only validation studies were included in the analysis. Another limitation of the review is that our assessment of the measurement properties of the instruments did not consider their methodological quality.

\section{Conclusion}

The purpose of the eleven presented instruments is to measure nurse professionalism, the most essential element in the nursing profession. Evaluation of the instruments' psychometric properties indicated that their quality was acceptable, and the methodologies used to assess these properties were sound. Instruments were developed from the two conceptual frameworks of Hall (1968) and Miller et al. (1993). The study and analysis of published studies and works dealing with professionalism can contribute to advancing the development of the nursing profession. However, studies related to professionalism in nursing are lacking in the Slovak Republic; hence we recommend addressing this issue in the Slovak sociocultural context, and examining the psychometric properties of instruments measuring professionalism. Results may provide support for the professional development of nurses, promoting higher levels of professionalism. A higher degree of professionalism in nurses can improve patient care and patient outcomes, and, in addition, improve the image of the nursing profession.

\section{Ethical aspects and conflict of interest}

The authors declare no potential conflicts of interest concerning the research, authorship, and / or publication of this article.

\section{Funding}

Dedicated to the project of the KEGA 008UK-4/2021 Professionalism and Ethics in Nursing.

\section{Author contributions}

Conception and design (DK, KŽ, MT), data collection (DK, MT), data analysis and interpretation (DK, KŽ, MT), manuscript draft (DK, KZ̆, MT), critical revision of the manuscript (KŽ), final approval of the manuscript (DK, KŽ, MT).

\section{References}

Adams, D., \& Miller, B. K. (2001). Professionalism in nursing behaviors of nurse practitioners. Journal of Professional Nursing, 17(4), 203-210. http://dx.doi.org/10.1053/jpnu.2001.25913

Adams, D., Miller, B. K., \& Beck, L. (1996). Professionalism behaviors of hospital nurse executives and middle managers in 10 western states. Western Journal of Nursing Research, 18(1), 77-88. https://doi.org/10.1177/019394599601800106

Baumann, A., \& Kolotylo, C. (2009). The Professionalism and

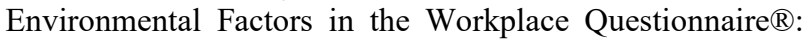
development and psychometric evaluation. Journal of Advanced Nursing, 65(10), 2216-2228.

http://dx.doi.org/10.1111/j.1365-2648.2009.05104.x 
Baumann, A., Crea-Arsenio, M., Akhtar-Danesh, N., FlemingCarroll, B., Hunsberger, M., Keatings, M., Elfassy, M. D., \& Kratina, S. (2016). Strategic workforce planning for health human resources: a nursing case analysis. Canadian Journal of Nursing Research, 48(3-4), 93-99. http://dx.doi.org/10.1177/0844562116680715

Castro E., Click, E., Douglas, S., \& Friedman, I. (2016). The professionalism of critical care nurse fellows after completion of the critical care nurse fellowship program. Journal for Nurses in Professional Development, 32(2), 8793. http://dx.doi.org/10.1097/NND.0000000000000226

Cerit, B., \& Dinç, L. (2013). Ethical decision-making and professional behavior among nurses: A correlation study. Nursing Ethics, 20(2), 200-212. http://dx.doi.org/10.1177/0969733012455562

Çelik, S., \& Hisar, F. (2012). The influence of the professionalism behavior of nurses working in health institutions on job satisfaction. International Journal of Nursing Practice, 18(2), 180-187. https://doi.org/10.1111/j.1440-172X.2012.02019.x

Chen, X., Yu, Q., Yu, F., Huang, Y., \& Zhang, L. (2019). Psychometric evaluation of the Chinese version of the Snizek-revised Hall's Professionalism Inventory Scale. Journal of International Medical Research, 47(3), 11541168. https://doi.org/10.1177/0300060518817401

De Braganca, A. V., \& Nirmala, R. (2017). Professionalism among nurses: a concept analysis. International Journal of Business and Management Invention, 6(7), 60-66.

Dikmen, Y., Karataş, H., Arslan, G. G., \& Ak, B. (2016). The level of professionalism of nurses working in a hospital in Turkey. Journal of Caring Sciences, 5(2), 95-102. http://dx.doi.org/10.15171/jcs.2016.010

Doost, F. H., Moghadas, T., Momeni, M., \& Rafiei, H. (2016). Factors influencing professionalism: a cross sectional study among Iranian registered nurses. Journal of Nursing and Health Sciences, 5(3), 47-49.

Dougherty, M. B., \& Larson, E. L. (2010). The Nurse-Nurse Collaboration Scale. The Journal of Nursing Administration, 40(1), 17-25.

http://dx.doi.org/10.1097/NNA.0b013e3181c47cd6

Fitzgerald, A. (2020). Professional identity: a concept analysis. Nursing Forum, 55(3), 447-472. http://dx.doi.org/10.1111/nuf.12450

Fukada, M. (2018). Nursing competency: definition, structure and development. Yonago Acta Medica, 61(1), 1-7. http://dx.doi.org/10.33160/yam.2018.03.001

Ghadirian, F., Salsali, M., \& Cheraghi, M. A. (2014). Nursing professionalism: an evolutionary concept analysis. Iranian Journal of Nursing and Midwifery Research, 19(1), 1-10.

Gunduzoglu, N. C., Korhan, E. A., Dilemek, H., \& Yilmaz, D. U. (2017). The validity and reliability of the Turkish form of the Nurses' Role and Competencies Scale. International Journal of Caring Sciences, 10(3), 1240-1247.

Hall, R. H. (1968). Professionalization and bureaucratization. American Sociological Review, 33(1), 92-104. http://dx.doi.org/10.2307/2092242

Hammer, D. P. (2000). Professional attitudes and behaviors: The "A's and B's" of professionalism. American Journal of Pharmaceutical Education, 64(4), 455-464. http://dx.doi.org/aj640420.pdf

Hampton, D. L., \& Hampton, G. M. (2000). Professionalism and the nurse-midwife practitioner: an exploratory study. Journal of the American Academy of Nurse Practitioners,
12(6), 218-225.

http://dx.doi.org/10.1111/j.1745-

7599.2000.tb00185.x

Hisar, F., \& Karadağ, A. (2010). Determining the professional behavior of nurse executives. International Journal of Nursing Practice, 16(4), 335-341.

http://dx.doi.org/10.1111/j.1440-172X.2010.01849.x

Hsieh, H.-F., \& Shannon, S. E. (2005). Three approaches to qualitative content analysis. Qualitative Health Research, 15(9), 1277-1288.

http://dx.doi.org/10.1177/1049732305276687

Ichikawa, N., Yamamoto-Mitani, N., Takai, Y., Tanaka, M., \& Takemura, Y. (2020). Understanding and measuring nurses' professionalism: development and validation of the Nurses' Professionalism Inventory. Journal of Nursing Management, 28(7), 1607-1618. http://dx.doi.org/10.1111/jonm.13116

Jahromi, M. K., Koshkaki, A. R., Poorgholami, F., \& Talebizadeh, M. (2018). A study of nurses' perception of professional values in the university hospitals affiliated with Jahrom University of Medical Sciences. Bangladesh Journal of Medical Science, 17(1), 47-51.

https://doi.org/10.3329/bjms.v17i1.35279

Jang, I., Kim, Y., \& Kim, K. (2016). Professionalism and professional quality of life for oncology nurses. Journal of Clinical Nursing, 25(19-20), 2835-2845.

http://dx.doi.org/10.1111/jocn.13330

Johnson, J. A. (2015). Nursing professionalism: innate, taught, or caught? Journal for Nurses in Professional Development, $31(2), 114-115$.

http://dx.doi.org/10.1097/NND.0000000000000149

Kim, Y.-S., \& Baek, H. (2007). Translation and validation of Korean version of Hall's Professionalism Inventory. Journal of Korean Academy of Nursing Administration, 13(4), 509515.

Kim-Godwin, Y. S., Baek, H. C., \& Wynd, C. A. (2010). Factors influencing professionalism in nursing among Korean American registered nurses. Journal of Professional Nursing, 26(4), 242-249.

http://dx.doi.org/10.1016/j.profnurs.2009.12.007

Konukbay, D., Yildiz, D., Fidanci, B. E., Yavuz, S., Akyol, M., \& Akbayrak, N. (2014). Determination of professional behaviours of nurses working in an education and research hospital. International Journal of Caring Sciences, 7(2), 633-641.

Lin, L. C., Lee, S., Ueng, S. W.-N., \& Tang, W.-R. (2016). Reliability and validity of the Nurse Practitioners' Roles and Competencies Scale. Journal of Clinical Nursing, 25(1-2), 99-108. http://dx.doi.org/10.1111/jocn.13001

Marcinowicz, L., Shpakou, A., Piatrou, S., Fejfer-Wirbal, E., Dudzik, A., Kalinowska, P., Palubinskaya, S., \& Wojnar, D. (2020). Behavioural categories of professionalism of nurses in Poland and Belarus: a comparative survey. Journal of Clinical Nursing, 29(9-10), 1635-1642. http://dx.doi.org/10.1111/jocn.15226

Miller, B. K. (1988). A model for professionalism in nursing. Today's OR Nurse, 10(9), 18-23.

Miller, B. K., Adams, D., \& Beck, L. (1993). A Behavioral Inventory for Professionalism in Nursing. Journal of Professional Nursing, 9(5), 290-295.

http://dx.doi.org/10.1016/8755-7223(93)90055-h

Mokkink, L. B., Terwee, C. B., Patrick, D. L., Alonso, J., Stratford, P. W., Knol, D. L., Bouter, L. M., \& de Vet, H. C. W. (2010). The COSMIN checklist for assessing the methodological quality of studies on measurement properties of health status measurement instruments: an international 
Delphi study. Quality of Life Research, 19(4), 539-549. http://dx.doi.org/10.1007/s11136-010-9606-8

Ouzzani, M., Hammady, H., Fedorowicz, Z., \& Elmagarmid, A. (2016). Rayyan - a web and mobile app for systematic reviews. Systematic Reviews, 5(1), 210. http://dx.doi.org/10.1186/s13643-016-0384-4

Pareek, B., Batra, K., \& Kalia, R. (2016). Development of Professionalism Assessment Scale for Nurse Educator. Asian Journal of Nursing Education and Research, 6(4), 506-510. http://dx.doi.org/10.5958/2349-2996.2016.00095.1

Poorchangizi, B., Borhani, F., Abbaszadeh, A., Mirzaee, M., \& Farokhzadian, J. (2019). Professional values of nurses and nursing students: a comparative study. BMC Medical Education, 19(1), 438. http://dx.doi.org/10.1186/s12909019-1878-2

Schmidt. B. J., \& McArthur, E. C. (2018). Professional nursing values: a concept analysis. Nursing Forum, 53(1), 69-75. http://dx.doi.org/10.1111/nuf.12211

Shepard, L. H. (2014). It takes a village to assure nurse professionalism. I-manager's Journal on Nursing, 3(4), 1-5.

Shohani, M., \& Zamanzadeh, V. (2017). Nurses' attitude towards professionalization and factors influencing it. Journal of Caring Sciences, 6(4), 345-357. https://doi.org/10.15171/jcs.2017.033

Skela-Savič, B., Hvalič-Touzery, S., \& Pesjak, K. (2017). Professional values and competencies as explanatory factors for the use of evidence-based practice in nursing. Journal of Advanced Nursing, 73(8), 1910-1923. http://dx.doi.org/10.1111/jan.13280

Snizek, W. E. (1972). Hall's Professionalism Scale: an empirical reassessment. American Sociological Review, 37(1), 109-114. http://dx.doi.org/10.2307/2093498

Tanaka, M., Taketomi, K., Yonemitsu, Y., \& Kawamoto, R. (2016). Professional behaviours and factors contributing to nursing professionalism among nurse managers. Journal of Nursing Management, 24(1), 12-20.

http://dx.doi.org/10.1111/jonm.12264

Tanaka, M., Yonemitsu, Y., \& Kawamoto, R. (2014). Nursing professionalism: a national survey of professionalism among Japanese nurses. International Journal of Nursing Practice, 20(6), 579-587.

http://dx.doi.org/10.1111/ijn.12201

Weis, D., \& Schank, M. J. (2009). Development and psychometric evaluation of the Nurses Professional Values Scale - Revised. Journal of Nursing Measurement, 17(3), 221-231. http://dx.doi.org/10.1891/1061-3749.17.3.221

Weis, D., \& Schank, M. J. (2017). Development and psychometric evaluation of the Nurses Professional Values Scale - 3. Journal of Nursing Measurement, 25(3), 400-410. https://doi.org/10.1891/1061-3749.25.3.400

Wilensky, H. L. (1964). The professionalization of everyone? American Journal of Sociology, 70(2), 137-158.

Wynd, C. A. (2003). Current factors contributing to professionalism in nursing. Journal of Professional Nursing, 19(5), 251-261. http://dx.doi.org/10.1016/S8755$\underline{7223(03) 00104-2}$ 